\title{
Consequences of the Treasury Single Account policy on the wealth of Nigerian commercial banks' shareholders
}

\section{Olayinka Moses}

School of Accounting and Commercial Law, Victoria Business School, Victoria University of Wellington, New Zealand and University of Jos, Nigeria

yinka.moses@vuw.ac.nz

\author{
Dimu Ehalaiye* \\ School of Accountancy, Massey Business School, \\ Massey University, New Zealand \\ o.ehalaiye@massey.ac.nz \\ Sebastian Seddi Maimako \\ University of Jos, \\ Jos, Nigeria \\ ssmaimako@yahoo.co.uk
}

Kayode Olusola Fasua

Nigerian College of Accountancy,

Kwall, Nigeria

kalovick@yahoo.com

Accepted manuscript. Please cite this article as:

Moses, O., Ehalaiye, D., Maimako, S., \& Fasua, K. (2018). Consequences of the treasury single account policy on the wealth of Nigerian commercial banks' shareholders. Emerging Markets Finance and Trade, 54(9), 2078-2092.

* Corresponding Author. Address for correspondence: School of Accountancy, Massey Business School, Massey University, Tennent Drive. Palmerston North 4474, New Zealand. Email: o.ehalaiye@massey.ac.nz 


\begin{abstract}
We examine the impact of the Nigerian government's Treasury Single Account (TSA) policy to withdraw the funds of Ministries, Departments and Agencies from commercial banks. Following the economic policy uncertainty theory, we use an event study methodology to measure the impact of the TSA policy on shareholders' wealth. Our results show that the announcements and subsequent final implementation of TSA policy caused negative abnormal returns and losses on the wealth of the commercial banks' shareholders. The paper contributes to the literature on stock market reaction to policy announcements and the unintended consequences government policy can have in an emerging economy.
\end{abstract}

Keywords: Treasury Single Account (TSA), Event Study, Valuation, Market Reaction, Nigeria 


\section{Introduction}

We investigate the consequences of implementing the Treasury Single Account (TSA) policy for Ministries, Departments and Agencies (MDAs) in Nigeria on the market valuation of Nigerian commercial banks. We use an event study methodology to evaluate the TSA policy's impact on the banks shareholders' wealth. The study is motivated from a priori theoretical framework that economic policy announcements by governments influence stock prices, particularly that increase in economic policy uncertainty are mostly associated with negative stock returns and increased stock volatility. The TSA system employs the use of a central accounting system for government cash resources, usually domiciled with a country's central bank and this offers a consolidated position of government cash resources at any given time. Commercial banks in Nigeria had for many years operated several bank accounts for MDAs in Nigeria and the implementation of the TSA policy was intended to withdraw these publicsector funds from commercial banks. The Buhari-led administration announced on August 7, 2015, that the implementation deadline for the TSA policy would be September 15, 2015, and the government maintained that this was a deadline that would not be changed nor postponed. This pronouncement and other subsequent directives steered investors' reactions from the day this announcement was first made to the final date of the policy implementation.

To measure the impact of this policy on the wealth of commercial banks' shareholders we employed an event study method, by examining the average abnormal returns and the cumulative average abnormal returns of the bank stocks during the event window from August 4, 2015 (Day -30) to October 13, 2015 (Day +20), with the main emphasis around the event date September 15, 2015 (Day 0), from September 10, 2015 (Day-3) to September 18, 2015 (Day +3). Our sample consists of all the commercial deposit money banks listed on the Nigerian Stock Exchange and we adopt a two-factor market model incorporating the market 
and the banking return indices to control for the industry fixed effects on the banking portfolio during the estimation window. We find, consistent with prior studies on emerging economies, that the market absorbed the information over several days surrounding the final implementation date and other relevant announcement dates. Our results show negative average abnormal returns from day -3 to 3 of the final implementation date of the TSA policy. The cumulative average abnormal return of the event period is -2.849 , statistically significant at the $1 \%$ level, suggesting that the Nigerian banks' valuation declined by over $2.8 \%$ consequent on the final implementation of the TSA. This is aside from previous negative losses due to announcements and information preceding the final implementation deadline. The results support the economic policy uncertainty theory which suggests that whenever government decision or stance on a given economic policy is unclear, investors tend to pause or completely withdraw their investments (especially in extreme situation of uncertainty) from financial markets. This situation is exacerbated by conflicting information dissemination on the part of the government or perhaps as with our study where previous attempts by the government to take a finalized stance on TSA policy had failed.

This study contributes to the literature on stock market reaction and the effects of economic policy uncertainty in several ways. Firstly, we note to the best of our knowledge, that this is the first study to evaluate the stock market's reaction to the implementation of the TSA policy on Nigerian banks valuation. This has significant implications considering the banking industry is a very important part of Nigeria's economy; a negative reaction by investors in the banking sector could undermine the health of the sector and the Nigerian economy as a whole. Secondly, this study employs a two-factor market model in its event study methodology approach. There is not one Nigerian study of this kind, and even in the literature generally, there are only a handful of studies that incorporate the industry specific return index in the methodology when 
estimating the market parameters plugged into regressions to measure reaction to various announcements. The two-factor market model provides robustness to the results found in this paper. Finally, this study significantly contributes to the literature on the evaluation of the influence of government policy announcements on financial markets, especially under a situation of uncertainty. While the investors' reactions to financial announcements such as dividends and earnings of firms have been studied extensively in the literature, there are few studies that have evaluated the market's reaction to government policy announcements. This study on the announcements relating to the implementation of the TSA system for MDAs in Nigeria makes a significant contribution to the literature in this regard.

The remainder of the paper is organized as follows. In section 2, we provide an overview of the TSA policy, alongside the theoretical implications of the policy. We present the event study methodology and model estimations in section 3. In section 4, we report and discuss our results and in section 5, we summarize the results and present our conclusions.

\section{Overview and theoretical implications of the Treasury Single Account (TSA) Policy in}

\section{Nigeria}

The TSA system provides a unified composition of bank accounts that presents a consolidated position of government cash resources (Pattanayak \& Fainboim, 2010). It employs the use of a single bank account or a set of connected bank accounts through which the government conducts all its receipts and payments, and can obtain a consolidated assessment of its cash standing at any given time (Yaker \& Pattanayak, 2012). The TSA system operates through a process where a bank, usually the country's central bank, maintains one operational account with or without sub-accounts, through which all government agencies' transactions go and are tracked, accounted for, and handled via sophisticated accounting systems (Yaker \& Pattanayak, 
2012). The system could still involve commercial banks performing retail banking functions for the government agencies, however, a daily clearing process and consolidation of cash balances into the Treasury Single Account would be in place. Hence, commercial banking accounts are organized as accounts with zero balances as any closing balance is sent to the TSA on a daily basis providing the government with a view of its total cash standing at the end of each day (Oyedele, 2015). A number of countries employ the use of centralized bank accounts in both developed economies such as the United Kingdom, France, the United States and New Zealand, and in emerging economies such as India, Indonesia, Brazil and Peru (Pattanayak \& Fainboim, 2010).

The economic rationale for the TSA policy is primarily cost minimization and efficient management of government cash resources. The efficient management of government resources is a significant factor in facilitating a country's economic development. Pattanayak \& Fainboim (2010) identify the economic benefits of TSA to include: access to complete and timely information on government cash resources; improvement of appropriation control, budget appropriation and execution; efficient cash management; reduction of bank fees and transaction costs; improvement in bank reconciliation and quality of fiscal data and the lowering of liquidity reserve needs. Many developing countries have fragmented systems for handling government transactions and lack a unified view and centralized control over government's cash resources. Thus, causing suboptimal utilization of cash that lay idle in numerous bank accounts held by spending agencies while the government seek out funds to execute its budget. The macroeconomic penalty suffered by such governments for this inefficiency in resource optimization includes but are not limited to: (i) idle cash balances in bank accounts often fail to earn market-related remuneration. (ii) governments being unaware of these resources, incurs avoidable borrowing costs on raising funds to cover its perceived 
cash shortage, and (iii) idle government cash balances in the commercial banking sector are not idle for the banks themselves, and can be used to extend credit and removing this extra liquidity through open market operations results in costs on the central bank of these countries (Pattanayak \& Fainboim, 2010). The TSA system addresses governments' need for effective control over cash resources, the reduction of the volatility of cash flows through the Treasury, and the maintenance of a lower cash reserve/buffer to meet unexpected fiscal volatility.

\subsection{The Economic Policy Uncertainty Theory and TSA in Nigeria}

Regulations and policy announcements by governments affect firms in several ways. Governments provide subsidies, levy taxes, set and enforce commercial laws and make policies that affect firms which investors react to. There are strong theoretical arguments and empirical evidence that demonstrate the significant effects of government policies on equity prices and stock price volatility (Knight, 2006; Füss and Bechtel, 2008; Boutchkova, et al., 2012). Furthermore, the effect of uncertainty about government's economic policy announcements (the economic policy uncertainty theory) leads to decline in equity returns (Dzielinski, 2012; Pastor and Veronesi, 2012; Brogaard and Detzel, 2015; Baker, Bloom, and Davis, 2016), reduction of investment and asset valuations (Ozoguz, 2009; Baker, et al., 2016) and a rise in stock price volatility (Baker, et al., 2016). This theoretical assertion suggests that when governments make economic policy announcements, especially when there is uncertainty around the implementation/effects of such policy announcements there is an anticipated market reaction, which is mostly negative. The implementation of the TSA policy in Nigeria was a significant government economic policy that was shrouded with uncertainty around when it was going to be implemented and how it would affect commercial banks in Nigeria.

\subsection{Background and Timeline of TSA policy implementation in Nigeria}


In Nigeria, significant discussion has ensued on the inefficient management of the government's cash resources over the last three decades [1]. The use of several bank accounts by MDAs in Nigeria has been linked to the state of inefficiency in cash management by Nigeria's government. According to Kanu (2016, pp. 43-44),

... until the introduction of TSA in Nigeria, MDAs which generate revenue, had multiple accounts in commercial banks, use part of the revenue generated to fund their operations and remit the surplus to the federation account. As a result, agencies pay into the government account what they deem fit... The result of this situation includes leakages of funds, embezzlement of public funds and the inability of the government to know the exact amount in its account.

In order to remedy this situation, the Federal Government of Nigeria under President Goodluck Jonathan implemented a pilot scheme of the TSA in 2012, utilizing a unified structure of accounting for some government MDAs (Udo, 2016). There were also further calls by the Central Bank of Nigeria (CBN) and the Office of the Accountant-General of the Federation (OAGF) for the full implementation of the TSA system. The CBN noted in a communique based on its November 2013 Monetary Policy Committee (MPC) meeting that,

The Federal Government debt has also risen phenomenally along with its deposits at the commercial deposit money banks, showing the Government as a net creditor to the system. This underscores the urgent need for the immediate implementation of the Treasury Single Account. The delay in returning government accounts to the Central Bank was seen as adding to the huge cost of government debt due to poor cash flow management (CBN, 2013, pp. 5-6).

The OAGF also directed all MDAs of the Federal Government to adhere to the TSA policy by closing all revenue accounts, such as those maintained in commercial banks by MDAs and 
transferring the fund balances to the TSA account operated by the CBN not later than February 28, 2015 (CBN, 2015). Despite these calls, a number of MDAs and their commercial banks did not comply with the policy and there were no repercussions for their non-compliance (Nweze, 2015; Bashir, 2016). It was argued by some public policy analysts that the non-implementation of the TSA policy for all MDAs was due to corruption and a lack of political will (Jegede, 2015).

Muhammad Buhari assumed the presidency of Nigeria on May 29, 2015, having won the election against Goodluck Jonathan. Tackling public sector waste especially within Nigeria's government was a hallmark of his election campaign. Thus, on August 7, 2015 in a circular by the Head of Civil Service of the Federation, which was reinforced through a press release on August 9, 2015 by President Buhari, all MDAs were directed to pay all receipts due to the Federal Government or any of its agencies into the TSA or designated accounts maintained and operated by the Central Bank of Nigeria $(\mathrm{CBN})$, except otherwise expressly approved (Kifasi, 2015a; Akande, 2015). The directive made clear that were no exemptions to any MDAs and that the deadline for compliance was September 15, 2015. Unlike previous directives, the Federal Government this time exerted pressure on the MDAs to comply with the policy. In a circular dated September 4, 2015, titled "Re: Introduction of Treasury Single Account (eCollection of Government Receipts)", the Head of Civil Service of the Federation made it clear that any Chief Accounting Officer who failed to comply with the implementation of the TSA policy would face sanctions (Kifasi, 2015b) [2].

Furthermore, on September 11, 2015, the Accountant General of the Federation reinforced the TSA policy implementation drive in a press release that stated there was no going back on September 15, 2015, compliance deadline for MDAs. This appeared to be an attempt to quash 
rumors and speculation that the September 15 deadline was going to be postponed (Udo, 2015). On September 15, 2015, the TSA policy came into full effect for all MDAs of the Federal Government of Nigeria. This final implementation deadline marked a turning point from previous efforts toward implementing the TSA system.

\subsection{TSA Policy and the Nigerian banking sector}

The financial services sector in general and especially the banking sector in particular play very important roles in the Nigerian economy. As of the last quarter of 2015, the financial services sector constituted about $26 \%$ of the equities market capitalization of the Nigerian Stock Exchange (NSE, 2015) with a capitalization of $\$ 2.52$ trillion (US\$12.63 Billion). Hence, policies that impact on this sector have the potential to affect the Nigerian economy as a whole.

Considering that the Nigerian commercial banks operated several bank accounts for the various MDAs and the TSA policy was going to cause their closure, there was apprehension that the policy would adversely affect the banking sector if implemented (Obinna, 2015). The major problem envisaged regarding the policy initiative was that it would impact negatively on the liquidity of the Nigerian banking sector. This was because Nigerian banks had over the years held significant public sector funds with which they traded. A report on the accounts of banks with the CBN on August 17, 2015, showed that banks' total public sector deposits at the time of TSA implementation on September 15, 2015, would stand at about $\$ 2.2$ trillion (US\$12.5 billion). These deposits would be completely withdrawn from these banks consequent on the TSA policy (Vanguard Editorial, 2015). There were also fears that the loss of deposit funds from the banking system would lead to an increase in money market rates and in the cost of capital (Eme et al., 2015; Kanu, 2016). Signaling a possible negative stock market reaction to 
commercial banks' share prices, investors anxiously weighed the consequences of the policy on the banking portfolio in the long run.

\subsection{Investor reactions to financial and nonfinancial announcements}

Previous studies on investors' reactions to various financial and nonfinancial announcements to the market are commonplace in the literature. The event study methodology is a recognized technique for evaluating the reaction of investors to disclosures made to the market. The seminal study by Fama, Fisher, Jensen and Roll (1969) shows that the market adapts to new information as investors endeavor to utilize information available to avoid uncertainty. Some of this information may be expected ahead of announcement day, following leakages to the market. A large number of event studies focus on the market reaction to financial announcements of firms, such as dividends (Olowe, 1998; Adelegan, 2003; Lyroudi, Dasilas \& Varnas, 2006; Campbell and Ohuocha, 2011), earnings (Ball and Brown, 1968; Alford et al., 1993; Berkman and Truong, 2009; Afego, 2013), and mergers, acquisitions and divestitures (Zhu and Jog, 2012; Hasan and Xie, 2013; Lee \& Park, 2016). Event studies in relation to market reaction to regulatory/policy announcements are less common and for developing and emerging countries such as Nigeria, they are sparse.

Olowe (2011) found that the announcement of new minimum capital requirements for Nigerian banks by the Central Bank of Nigeria in 2004 had a positive impact on the quoted securities on the Nigerian stock market. Osuala, Nto and Akpan (2013) found that the sudden removal of the chief executives of five banks listed on the Nigerian Stock Exchange in 2009 did not significantly impact on the stock prices of the banks involved. There are no specific studies that have examined the market's reaction to the announcement of the Treasury Single Account (TSA) policy in Nigeria. Thus, given the significance of the implementation of the full TSA 
policy on September 15, 2015, on Nigerian banks, we investigate the impact of the implementation on the share prices of Nigerian banks within the Nigerian stock market using the event study methodology.

\section{Data and Sample Selection}

Data for listed commercial banks on the Nigerian Stock Exchange was sourced from Thomson Reuters Datastream database (Datastream). The sample consists of all the listed commercial deposit money banks with shares that are actively traded on the Nigerian Stock Exchange (see Appendix S1 in the supplementary material, available online). As at August 4, 2015, there were 15 commercial deposit money banks listed on the Nigerian Stock Exchange. Daily closing prices and market and banking industry indices for the study were obtained from Datastream for the period covering August 4, 2014, to October 13, 2015. The estimation period for the study comprised of 250 trading days before the event period (i.e. -280 days prior to the implementation deadline, until day -31). The event window encompassing the different event periods comprised 51 days from -30 days before the final implementation day until 20 days after. Following prior literature on event studies for emerging economies (Feng and Xu, 2007; Campbell and Ohuocha, 2011; Lee and Park, 2016), we calculated daily stock returns as the difference in the natural logarithm of closing stock prices for two consecutive trading days:

$$
R_{i t}=\ln \left(\frac{P_{i t}}{P_{i t-1}}\right) \times 100
$$

Where $R_{i t}$ is daily actual return of stock $i$ at time $t$; $P_{i t}$ is daily price of individual stock $i$ at time $t$, and $P_{i t-1}$ is the one-day lagged stock price of company $i$ at time $t$ - 1 . The stock prices calculated using the above formula provided returns for the listed banks. Similarly, daily returns are calculated for the stock market indices using the Nigerian Stock Exchange All Share 
Index and Stock Exchange Banking Index data- which are proxies for the value-weighted market and industry portfolio returns, respectively.

\subsection{Event Study Method}

Consistent with the standard event study method applied by Lee and Park (2016), we use the ordinary least squares regression market model. Our study, however, differs from Lee and Park (2016) in that we adopt the two-factor market model incorporating market and industry return indices. The Banking Index is introduced to control for the industry effect and systematic return variation that is independent of the event under study. This is relevant because the 15 banks studied represents the entire commercial banks' portfolio returns traded on the Nigerian Stock Exchange during the estimation window, hence all the banks would be affected by similar industry effects. The two-factor model used to estimate parameters for computing the abnormal return is specified below:

For any security $i$, the two-factor market model is applied by first regressing individual securities' daily returns on the market and industry's daily returns specified as:

$R_{i t}=\propto_{i}+\beta_{1 i} R_{m t}+\beta_{2 i} I_{n d}+\varepsilon_{i t}$

Where:

$R_{i t} \quad=$ Period return for security $i$

$\propto_{i} \quad=$ Constant estimate for security $i$

$\beta_{1 i} \quad=$ Estimated Beta (slope of coefficient) for return on Nigeria Stock Exchange All

Share Index- as proxy for the market index

$R_{m t}=$ Return on the Nigeria Stock Exchange All Share Index portfolio in period $t$

$\beta_{2 i}=$ Estimated Beta (slope of coefficient) for return on Nigeria Stock Exchange Banking Index 
$\operatorname{Ind}_{t}=$ Return on Nigeria Stock Exchange Banking Index portfolio in period $t$

$\varepsilon_{i t} \quad=$ Residual term

We run regressions of individual stock returns $\left(R_{i t}\right)$ on the market $\left(R_{m t}\right)$ and industry portfolio $\left(\operatorname{Ind}_{t}\right)$ returns to determine the parameters of $\alpha_{i}, \beta_{1 i}$ and $\beta_{2 i}$ in equation (1) over the estimation window from -280 to -31 . We derive the residual term $\left(\varepsilon_{i t}\right)$ by plugging in the estimated parameters of $\widehat{\alpha}+\hat{\beta}$ as in equations (2) - (3) presented below. For the event window $-30,+20$, we computed abnormal returns $\left(A R_{i t}\right)$ of individual stocks using equation (4). Abnormal returns is the difference between the actual daily return and the predicted two factor market model returns in equations (2) and (3).

$$
\begin{aligned}
& \widehat{R_{l t}}=\widehat{\alpha}+\hat{\beta} R_{m t}+\hat{\beta} I n d_{t} \\
& \widehat{\varepsilon_{l t}}=R_{i t}-\widehat{R_{l t}} \\
& A R_{i t}=R_{i t}-\left(\widehat{\alpha}+\hat{\beta} R_{m t}+\hat{\beta} I n d_{t}\right)
\end{aligned}
$$

The average abnormal return on day $t\left(A A R_{t}\right)$ is the mean abnormal return $\left(A R_{i t}\right)$ across the event window for all individual stocks as in equation (5) below:

$$
A A R_{t}=\frac{1}{N} \sum_{i=1}^{N} A R_{i t}
$$

The t-statistics for the daily AARs are calculated using equation (6):

$$
t_{A A R_{t}}=\frac{A A R_{t}}{S\left(A A R_{t_{-280}-t_{-31}}\right)}
$$

Considering all 15 banks are affected by the same event, some amount of cross-sectional correlation in abnormal returns is expected (Brown and Warner, 1985), which induces 
misspecification in t-statistics that assume sample abnormal returns are independently distributed. Following Brown and Warner (1985) and Lee and Park (2016), we compute the tstatistic using the time-series standard deviation of daily average abnormal returns during the estimation period, which is well specified in the presence of cross-sectional dependence.

The cumulative average abnormal return $\left(C A A R_{t_{1}-t_{n}}\right)$ during a given event period is computed using equation (7) while the t-statistic is estimated using equation (8):

$C A A R_{t_{1}-t_{n}}=\sum_{t_{1}}^{t_{n}} A A R_{i t}$

where day $t_{1}$ is the first day in the given event period and day $t_{n}$ is the last day in the given event period.

$t_{C A A R_{t_{1}-t_{n}}}=\frac{\operatorname{CAAR}_{t_{1}-t_{n}}}{\frac{S\left(C A A R_{-280}-t_{-31}\right)}{\sqrt{N}}}$

$S\left(C A A R_{t_{1}-t_{n}}\right)$ is the standard deviation for the estimation window commencing -280 and ending -31 days, and $N$ represents the number of partitioned event periods.

\section{Results}

Table 1 presents average and cumulative abnormal returns and the t-statistics for each event day during the event window. From Table 1, there are several signals in relation to the market reaction to banks' share prices following various announcements about the final implementation day (September 15) of the TSA policy in Nigeria. On September 15, the event day (Day 0) in Table 1 shows negative average abnormal returns (AAR) of $-0.67 \%$ and cumulative average abnormal returns (CAAR) of $-2.97 \%$. As expected with the nature of semiefficient markets, information into the market is absorbed over a number of days by market participants (MacKinlay, 1997; Hood, 2012). This is consistent with prior studies on emerging stock markets and the Nigerian capital market in particular, as our results demonstrate that the 
Nigerian capital market is not efficient in the strong-form based on the efficient market hypothesis (Olowe, 1998; Magnusson and Wydick, 2002). The market reaction to the implementation deadline of the TSA policy was absorbed by the market over several days, with a delayed reaction to the final implementation of the TSA policy, thus, reporting a statistically significant AAR of $1.185 \%$ on the day following the final implementation day $($ Day +1$)$. Furthermore, three days before the event day (Day -3) and the day following the event day $($ Day +1$)$ reflect the impact of the event on the market. Day (-3), Thursday September 10, 2015 was when investors started realizing the TSA policy was going to be a reality in the banking sector, as statements in that week by key stakeholders such as the Accountant General of the Federation and the Head of Civil Service reinforced the view that the implementation deadline of September 15, 2015, was not going to be postponed or changed (Kifasi, 2015b; Udo, 2015). The market had a negative reaction on this day (Day -3) with an AAR of -1.432 , which was statistically significant at the $1 \%$ level (with t-statistic 2.409). This is expected as firstly, when the market became aware of the timeline for the TSA policy implementation from August 9, there was the view that as with previous government announcements on TSA policy which did not eventually get enacted due to a lack of administrative and political will, this new timeline would probably not be implemented. Secondly, financial pundits and analysts' reviews of the proposed policy's impact on the economy remained mixed in this period. While public policy pundits and general public opinion favored the TSA policy as an effective avenue for saving Nigeria from wasting billions, banking professionals suggested the contrary. Commercial banks' treasurers had struggled with the move by the government to implement a similar policy in the past due to their perception of a likely negative impact on banks' profitability, liquidity and funds available in the financial system for credit. In many emerging economies, government spending constitutes a significant financial injection of funds to the financial 
system; thus, news of fund withdrawals from financial institutions will no doubt signal several adverse effects on the valuation of the custodians of those funds (commercial banks).

\section{Insert Table 1}

\section{Insert Table 2}

Furthermore, prior to the TSA final implementation deadline (i.e. our event day), a huge blow had been dealt to the valuation of commercial banks with the August 9 announcement of the proposed TSA implementation. In particular, financial analysts' caveats on the policy published in the Vanguard newspaper on Monday, August 17, 2015 (Day -21), sent panic waves across the banking portfolio, as returns plummeted. The newspaper for the first time estimated the monetary worth of deposits to be pulled out of the banking system, which perhaps caused the adverse reaction seen in the returns of the banks [3]. This can be observed from Table 1, where the AAR of the commercial banks in Nigeria was negative on August 17 (Day -21) and around day -21 due to this information which highlighted how the TSA policy would impact on credit flows. The AAR for the day (Day -21) was $-1.415 \%$ and statistically significant at the $1 \%$ level, with a CAAR of $-6.804 \%$. Of note is that this was the day the value of the commercial banks suffered the lowest negative (loss) during the event window. The effect followed through until August $20^{\text {th }}$ (Day -18) [4]. Overall, the results from Table 1 show that the TSA policy implementation brought significant loss to the valuation of banks on the Nigerian Stock Exchange, especially around the dates of significant announcements relating to the TSA policy and also around the final implementation date of the policy. On the balance investors reacted negatively to the TSA policy announcements and its implications by withdrawing investments in the banking portfolio, thus impacting negatively on the market value of banks. These findings are in sync with the economic policy uncertainty theory that 
investors react negatively to policy announcements by governments that do not provide certainty to market participants.

In Table 2, the CAARs for several event periods within the event window are consistently negative and statistically significant across the announcement intervals leading to the final implementation period. The CAAR from day -30 to -1 before the event day is negative $(-2.291)$ and statistically significant at the $1 \%$ level (t-statistic 6.343). This shows that the CAAR tends to drift in the same direction across the main event periods within the entire window. The mean negative cumulative excess returns decreased from -2.291 to -1.872 for the entire window of 30,20 , but remained statistically significant at the $1 \%$ level (t-statistic 6.758). This is further evidence that the impact of the implementation of TSA on the valuation of commercial banks in Nigeria was not mitigated even after the final implementation day, as the market failed to adjust immediately. The main period of interest in our study is $-3,3$ of the event window which signifies the CAAR in the period surrounding the final implementation of the TSA policy in Nigeria. The CAAR for $-3,3$ indicate a negative market reaction of -2.849 and statistically significant at the $1 \%$ level (t-statistic 3.810). The results of the post-event periods corroborate with our expectations as the market had a revision on the banks' valuation post implementation of the TSA. This is not unconnected with the CBN's efforts to minimize the negative impact of the credit shortage created following the full implementation of the TSA policy. This can be observed from Table 2 alternative event windows $(1,10)$ and $(4,11)$ which are not statistically significant, but signify the commencement of the revision by the market which was peaked at the tail window of $(12,20)$ with a positive CAAR of 1.405 and statistically significant at the $1 \%$ level. 
The negative cumulative average abnormal returns associated with the TSA policy implementation's impact on commercial banks' valuation becomes clearer when observed from the graphs used in plotting the CAAR on days surrounding event periods. These results are presented in Figures 1 and 2 where a visual inspection of the plots reveals that the CAARs over the specific event periods are all significantly negative.

\section{Insert Figure 1}

Figure 1 depicts the CAAR around TSA announcements during the event period $(-30,-1)$, encompassing periods when the Presidency made public the plan to implement the policy. It further shows that the press release from the Accountant-General of the Federation on the "nogoing-back' stance on the government's intention and the released analysts' forecasts on the expected impact of the policy implementation on banks' liquidity, drove investors into the negative reaction observed. The impact was most significant for the period between days -21 to -18 , as discussed earlier. This first impact seems to have hit the valuation of the banks significantly.

\section{Insert Figure 2}

A closer examination of Figure 2 reveals that although the banks' values improved marginally after the initial information about the TSA policy was received by the market, they however, lost value on the days surrounding the final implementation, even though the impact of the latter loss is less (i.e. -4.051 at the end of day 3 compared to previous announcement event periods of -7.405 for day -18). This suggests that the largest loss suffered was during event periods surrounding the announcements leading to the final implementation of the policy. The results make intuitive logic, as investors were expected to react most in the first instance when the information is made available to the market. Subsequent reactions are due to the unknown 
implications of the policy outcome, rather than the information about the policy. In addition, the uncertainty around the implementation of the TSA policy especially from the various announcements that preceded the final implementation day of the policy made the market to react negatively to the preceding announcements made about the TSA policy before the final implementation day. By the final implementation day the uncertainty around whether the policy would be implemented or not (and its implications) had been reduced because there was more information about the TSA policy available to investors, hence, the market reaction was of lesser impact on the final implementation day. Furthermore, Figure S1 (see the supplementary material, available online) confirms that the overall consequence of the TSA policy on the commercial banks' market valuations in Nigeria was indeed that of a downward trend. Careful inspection reveals that for periods surrounding the final implementation deadline (the event day), investors underpriced the stocks of the banks from day -1 and this persisted until day 3 .

\subsection{Additional Tests}

We conducted additional sensitivity and robustness tests to support our initial results. The results are reported as supplementary material, available online.

First, we re-estimated AAR and CAAR using a shorter estimation window of 150-day [-180, 31] as an alternative to the 250-day employed in the initial test. Consistent with our initial results, the shorter estimation window shows that on the final implementation day (September 15) AAR for banks in Nigeria was $-0.711 \%$ with a CAAR of $-2.645 \%$. The next day (Day +1$)$ records AAR (CAAR) of $-1.080 \%(-3.724 \%)$ with the AAR statistically significant at $10 \%$ level (See Tables S1 and S2 available online as supplementary material). 
Second, we conducted an additional test using the policy announcement date only as the event day. We also used the shorter estimation window (i.e. 150-day) to test for the consistency of the length of estimation window for the announcement date alone. The results reported in Tables S3a, S3b, S4a and S4b do affirm that the announcement of TSA policy like its implementation resulted in shareholders' wealth loss for banks in Nigeria.

Finally, to minimize the effect of other price sensitive events happening within the individual banks in our sample, with possible confounding effect during the event period, we conducted a search on FACTIVA [5] for such events from 10 September 2015 to 18 September 2015 [6].

\section{Conclusion, Limitation and Future Research}

This paper examines the consequences of the TSA policy implementation on the valuation of commercial banks in Nigeria, using stock returns as a benchmark. Consistent with prior findings (Fama, et al., 1969; Louhichi, 2008) that share prices reveal information to market participants about firms affected by new information or policy implementation, our results show that the Nigerian stock market reacted to the announcement and subsequent final implementation deadline of the policy in a negative manner. This negative market reaction is consistent with the a priori expectation that uncertainty about government's economic policy announcements leads to decline in stock returns (Pastor and Veronesi, 2012; Brogaard and Detzel, 2015). The market valuation for Nigerian commercial banks dropped from the period when the government first informed the public of the proposed plan to withdraw MDAs' funds from commercial banks. Anxious about the uncertainties of TSA implementation and perhaps as a cautionary measure, investors withdrew their investments due to the insinuation of reduced liquidity and lending incapability of the commercial banks ex ante the TSA implementation. 
Furthermore, our study reveals that the portfolio returns of commercial banks in Nigeria remained abnormally low for most days in the event window, particularly for the days with specific announcements preceding the event day, which recorded negative AARs with no statistical significance. The recovery seen in the banks' portfolios after the final day of the event and other short-term recovery is perhaps associated with the CBN's proposed stabilization policies to mitigate the adverse effects of the TSA policy on liquidity in the banking system. Specifically, the CBN on September 21, 2015, reduced the Cash Reserve Ratio (CRR) from $31 \%$ to $25 \%$ as part of a mechanism to reduce the negative impact on the banking system (CBN, 2015b). The apex bank, following pressures on the banking system in the country, took this decision to enable release of liquidity to banks and to allow banks to adjust to the adoption of the TSA in the short run. However, the CBN stabilization policy led to only a mild recovery in banks' valuations as the banks' portfolios continued to oscillate within an overall negative course as at the last date of our event window. As regards the economic policy uncertainty theorization, the $\mathrm{CBN}$ stabilization policy effort had a mitigating impact, especially in the short-term of reducing the uncertainties around the negative implications of the TSA policy on Nigerian banks; hence inducing the recovery seen by share prices of the banks after the CBN's stabilization policy was announced.

Finally, we present evidence robust under a shorter estimation window and alternate event period (announcement date) validating the results found that the valuation of commercial banks in Nigeria was negatively impacted during the event period of our study. Another possible explanation for the negative reaction of the TSA policy final implementation deadline on the banks' valuations is the forecast lowering profitability of the banks post implementation. Investors' perceptions of the policy reflect that of a possible negative impact on banks' growth and overall profitability. This result is not unusual as the principal function of banks in Nigeria, 
like most emerging markets, is to mobilize deposits and intermediate by redistributing funds among surplus and deficit spending units of the economy (Olowe, 2011).

As a way to mitigate the limitation of this study, it would be pertinent to identify specific immediate and remote economic costs of the policy on commercial banks' business models and their financial performance as key factors explaining the effects of the policy, factors which we have not investigated due to the timing of our study. The question of how the TSA policy impacts on the Nigerian economy and the benefit or burden it has had on the economic system is yet to be addressed and is a starting point for subsequent research. Our work focuses on explaining the consequences of the TSA policy announcements and final implementation cutoff date on commercial banks' market valuations in Nigeria, and we have presented evidence to show that banks lost significant market value following announcements and the subsequent final deadline for the TSA implementation in Nigeria.

\section{Acknowledgements}

We would like to thank two anonymous referees and the 2016 conference participants at the African Accounting and Finance Association Conference, in Nairobi, Kenya for their helpful comments. We are also grateful to The School of Accountancy, Massey University, New Zealand; The School of Accounting and Commercial Law, Victoria University of Wellington, New Zealand; and University of Jos, Jos, Nigeria for their financial support.

\section{Notes}

1. A significant amount of literature discusses financial imprudence, waste and corruption issues related to the management of government finances in Nigeria. Transparency 
International (2015) ranked Nigeria as $136^{\text {th }}$ out of the 168 countries assessed for public sector corruption in 2015. Further discussion on this can be seen in Iyoha and Oderinde (2010) and Osoba (1996).

2. The circular, No. HCSF/428/S.1/125, read: Further to the Circular Ref. No. HCSF/428/S.1/120 of August 7, 2015, on the above subject matter, it has been observed that a number of Ministries, Departments and Agencies (MDAs) of the Federal Government are yet to comply with the directive therein...In this regard, His Excellency Mr President has directed that all MDAs are to comply with the instructions on the Treasury Single Account (TSA) unfailingly by Tuesday, 15th September 2015. In line with the TSA policy, all receipts due to the Federal Government or any of her agencies shall be paid into a common account: Accountant-General (Federal Sub-Treasury), Account No. 3000002095 maintained with the Central Bank of Nigeria, CBN, except otherwise expressly approved.

3. In an article titled 'Treasury Single Account: Bank deposit loss may hit N2 trillion', the Vanguard newspaper reported that the nation's banks would be losing about 2 trillion Naira in deposits to the Central Bank of Nigeria, with the implementation of the Treasury Single Account (Vanguard Newspaper, Monday, August 17, 2015).

4. According to Leadership newspaper (2015), on August 27, 2015, there was some good news for the banking industry. The news was that the CBN had approved the request of deposit money banks to provide financial accommodation to state governments to enable them pay the backlog of salaries of their workers. This news was interpreted as positive information by investors, as commercial bank lending to State governments was a significant means of generating income for the banks. Investors' positive reaction to this 
news over a few days based on the efficiency level of the market, coupled with an absence of any adverse news about the TSA policy during the period of August 27-September 3, may have accounted for the positive AAR recorded during this period.

5. FACTIVA is a business information and research tool owned by Dow Jones and Company, USA. It aggregates content from both licensed and free sources and provides search, alerting, dissemination, and other information management capabilities. For more information please see https://global.factiva.com/.

6. On cross-checking, we found on the 11th September 2015 as reported by Reuters (2015) that StanbicIBTC Bank was being investigated by Financial Reporting Council of Nigeria over alleged wrongful disclosure regarding fees owed to its parent, South Africa's Standard Bank. We interpret this news to be price sensitive in line with previous literature suggesting a decline in stock price of companies in violation of regulations (Fich \& Shivdasani, 2007). To correct for this confounding event, we exclude StanbicIBTC from our sample and reestimated our abnormal returns for the remaining 14 banks in the sample and found the results (unreported) to be qualitatively similar. Overall, the main results alongside the reduced sample excluding the bank with confounding event provide support that the TSA policy adversely affected the valuation of banks in Nigeria. 


\section{References}

Adelegan, O. J. (2003), "Capital market efficiency and the effects of dividend announcements on share prices in Nigeria”, African Development Review, Vol. 15 No. 2-3, pp. 218-236.

Afego, P. N. (2013), "Stock Price Response to Earnings Announcements: Evidence from the Nigerian Stock Market”, Journal of African Business, Vol. 14 No. 3, pp. 141-149.

Akande, L. (2015), "Buhari orders federal ministries, agencies to open treasury single account" Press release, Premium Times, August 9, 2015.

Alford, A., Jones, J., Leftwich, R. and Zmijewski, M. (1993), "The relative informativeness of accounting disclosures in different countries", Journal of Accounting Research, Vol. 31, pp. 183-223.

Baker, S. R., Bloom, N. and Davis, S. J. (2016), "Measuring Economic Policy Uncertainty", The

Quarterly Journal of Economics, Vol. 131, No. 4, pp. 1593-1636.

Ball, R. and Brown, P. (1968), “An empirical evaluation of accounting income numbers", Journal of Accounting Research, Vol. 6 No. 2, pp. 159-178.

Bashir, Y.M. (2016), "Effects of Treasury Single Account on Public Finance Management in Nigeria”, Research Journal of Finance and Accounting, Vol. 7 No. 6, pp. 164-170. 
Berkman, H. and Truong, C. (2009), "Event day 0? After-hours earnings announcements", Journal of Accounting Research, Vol. 47 No. 1, pp. 71-103.

Brogaard, J. and Detzel, A. (2015), “The asset-pricing implications of government economic policy uncertainty”, Management Science, Vol. 61 No.1, pp. 3-18.

Brown, S. J. and Warner, J. B. (1985), "Using daily stock returns: The case of event Studies", Journal of Financial Economics, Vol. 14 No. 1, pp. 3-31.

Boutchkova, M., Doshi, H., Durnev, A. and Molchanov, A. (2012), "Precarious politics and return volatility", Review of Financial Studies, Vol. 25, No. 4, pp. 1111-1154.

Campbell, K. and Ohuocha, C. (2011), “The stock market reaction to stock dividends in Nigeria and their information content", Managerial Finance, Vol. 37 No. 3, pp. 295-311.

Central Bank of Nigeria (2013), “Communiqué No. 92 of the Monetary Policy Committee Meeting”, November 18-19, 2013. Available at:

http://www.cbn.gov.ng/documents/mpc.asp

Central Bank of Nigeria (2015), “Commencement of Federal Government's independent revenue

e-collection scheme under the Treasury Single Account (TSA) initiative”. Circular to All Deposit Money Banks (DMBs), February 25, 2015. 
Central Bank of Nigeria (2015b), “Communiqué’ No. 103 of the Monetary Policy Committee Meeting”, September 21-22, 2015. Available at:

http://www.cbn.gov.ng/documents/mpc.asp

Dzielinski, M. (2012), "Measuring economic uncertainty and its impact on the stock market”, Finance Research Letters, Vol. 9, No. 3, pp. 167-175.

Eme, O. I., Chukwurah, D. C. and Iheanacho, E. N. (2015), “An analysis of pros and cons treasury single account policy in Nigeria", Arabian Journal of Business and Management Review (Oman Chapter), Vol. 5 No. 4, pp. 20.

Fainboim, I. and Pattanayak, S. (2010), “Treasury Single Account: Concept, Design, and Implementation Issues”, IMF Working Paper No. WP/10/143, pp. 1-45, May 2010.

Fama, E. F., Fisher, L., Jensen, M. C. and Roll, R. (1969), “The adjustment of stock prices to new information”, International Economic Review, Vol. 10 No. 1, pp. 1-21.

Feng, L. and Weihe Xu. (2007), "Has the Reform of Nontradable Shares Raised Prices? An Event

Study Analysis", Emerging Markets Finance and Trade, Vol. 43, No. 2, pp. 33-62.

Fich, E. M. and Shivdasani, A. (2007), "Financial fraud, director reputation, and shareholder wealth", Journal of Financial Economics, Vol. 86, No. 2, pp. 306-336. 
Füss, R., and Michael M. B. (2008), "Partisan politics and stock market performance: The effect

of expected government partisanship on stock returns in the 2002 German federal election." Public Choice, Vol. 135, No. 3, pp. 131-150.

Hasan, I. and Xie, R. (2013), "Foreign bank entry and bank corporate governance in China”, Emerging Markets Finance and Trade, Vol. 49 No. 2, pp. 4-18.

Hood, M. (2012), “The Tiger Woods scandal: a cautionary tale for event studies”, Managerial Finance, Vol. 38 No. 5, pp. 543-558.

Iyoha, F. O. and Oyerinde, D. (2010), “Accounting infrastructure and accountability in the management of public expenditure in developing countries: A focus on Nigeria", Critical Perspectives on Accounting, Vol. 21 No. 5, pp. 361-373.

Jegede, M. (2015), "Buhari and the Treasury Single Account", Daily Trust, 27 September 2015.

Kanu, C. (2016), "Impact of Treasury Single Account on the Liquidity”, ABC Journal of Advanced Research, Vol. 5 No. 1, pp. 43-52.

Kifasi D.I. (2015a), "Re: Introduction of Treasury Single Account (TSA), E-collection of government receipts", Circular HCSF/418/S.1/120 from the Head of the Civil Service of the Federation, August 72015. 
Kifasi D.I. (2015b), "Re: Introduction of Treasury Single Account (TSA) (e-Collection of Government Receipts)", Circular HCSF/418/S.1/125 from the Head of the Civil Service of the Federation, September 4, 2015.

Knight, B. (2006), "Are policy platforms capitalized into equity prices? Evidence from the Bush/Gore 2000 presidential election." Journal of Public Economics, Vol. 90, No. 4 pp. 751-773.

Leadership newspaper (2015), "Salary arrears: CBN okays Bank loans for 27 states”, Available at: $\quad$ http://leadership.ng/news/456555/salary-arrears-cbn-okays-bank-loans-for-27-

states

Lee, H. and Park, K. I. (2016), "Market Valuation Effect of Foreign Asset Divestitures in an Emerging Economy: Korean Evidence”, Emerging Markets Finance and Trade, Vol. 52 No. 1, pp. 136-153.

Louhichi, W. (2008), “Adjustment of stock prices to earnings announcements: evidence from Euronext Paris", Review of Accounting and Finance, Vol.7 No. 1, pp. 102-115.

Lyroudi, K., Dasilas, A. and Varnas, A. (2006), "The valuation effects of stock splits in NASDAQ”, Managerial Finance, Vol. 32 No. 5, pp. 401-414.

MacKinlay, A. C. (1997), "Event studies in economics and finance”, Journal of Economic Literature, Vol. 35 No. 1, pp. 13-39.

Magnusson, M. and Wydick, B. (2002), "How efficient are Africa's emerging stock 
markets?” Journal of Development Studies, Vol. 38, No. 4, pp. 141-156.

Nweze, C. (2015), “Banks fail CBN's directive on MDAs' accounts remittances”, The Nation, 15

July 2015.

Obinna, C. (2015), "Banks face liquidity strain as FG fully enforces Treasury Single Account", Thisday, 11 August 2015.

Olowe, A. R. (1998), "Stock splits and the efficiency of the Nigerian stock market", African Review of Money Finance and Banking, Vol.1 No. 2, pp. 97-126.

Olowe, A. R. (2011), "The impact of the 2004 bank capital announcement on the Nigerian stock Market”, African Journal of Economic and Management Studies, Vol. 2 No. 2, pp. 180201.

Osoba, S. O. (1996), "Corruption in Nigeria: historical perspectives", Review of African Political Economy, Vol. 23 No. 69, pp. 371-386.

Ozoguz, A. (2009), 'Good times or bad times? Investors' uncertainty and stock returns", Review

of Financial Studies, Vol. 22 No. 11, pp. 4377-4422. 
Osuala, A. E., Nto, P. O. and Akpan, S. F. (2013), “The Information Content of Sudden Removal

of Corporate Chief Executives-Evidence from the Nigerian Banking Sector", International Journal of Economics and Finance, Vol 5 No. 8, pp. 101.

Oyedele, T. (2015), “Treasury Single Account and Taxation”, Available at: http://pwcnigeria.typepad.com/files/tsa-and-tax---part-1-bizday.pdf

Pastor, L. and Veronesi, P. (2012), "Uncertainty about government policy and stock prices". The

Journal of Finance, (Vol. 67, No. 4, pp.1219-1264.

Reuters (2015), “Nigeria's regulator investigates Stanbic over fees disclosure”, Available at: http://www.reuters.com/article/nigeria-stanbic-ibtc-bk-idUSL1N11H0I420150911

The Nigerian Stock Exchange [NSE] (2015), NSE Q4 2015 Fact Sheet. The Nigerian Stock Exchange, Lagos, Nigeria.

Transparency International (2015), “Corruption perceptions Index 2015”, Available at: http://www.transparency.org/cpi2015

Vanguard Editorial (2015), “Treasury Single Account: Bank deposits loss may hit $¥ 2$ trn”, Vanguard, 17 August 2015. 
Udo, B. (2015), “Treasury Single Account: No going back on Sept. 15 deadline - Accountant General”, Premium Times, 11 September 2015.

Udo, B. (2016), "15 things to know about Treasury Single Account (TSA)", Premium Times, 7

March 2016.

Yaker, I. F. and Pattanayak, S. (2012), Treasury Single Account: An Essential Tool for Government Cash Management, International Monetary Fund, Washington D.C.

Zhu, P. and Jog, V. (2012), "Impact on target firm risk-return characteristics of domestic and cross-border mergers and acquisitions in emerging markets", Emerging Markets Finance and Trade, Vol 48. No 4. pp. 79-101. 
Table 1: Average Abnormal Returns (AARs) during the Event Window (Estimation window: -280, -31)

\begin{tabular}{|c|c|c|c|c|}
\hline Date & Event Window & AARs (\%) & t-value & CAARs (\%) \\
\hline 04- August & -30 & -0.570 & 0.959 & -0.570 \\
\hline 05-August & -29 & -0.568 & 0.956 & -1.138 \\
\hline 06-August & -28 & -0.905 & 1.522 & -2.042 \\
\hline 07-August & -27 & 0.350 & 0.589 & -1.692 \\
\hline 10-August & -26 & -0.223 & 0.375 & -1.915 \\
\hline 11- August & -25 & -0.908 & 1.528 & -2.823 \\
\hline 12- August & -24 & -0.794 & 1.336 & -3.617 \\
\hline 13-August & -23 & -0.599 & 1.008 & -4.216 \\
\hline 14- August & -22 & -1.173 & $1.974 * *$ & -5.390 \\
\hline 17-August & -21 & -1.415 & $2.380 * *$ & -6.804 \\
\hline 18-August & -20 & -0.428 & 0.720 & -7.232 \\
\hline 19- August & -19 & -1.210 & $2.035 * *$ & -8.442 \\
\hline 20-August & -18 & 1.037 & $1.744 *$ & -7.405 \\
\hline 21-August & -17 & -0.497 & 0.836 & -7.902 \\
\hline 24-August & -16 & 0.003 & 0.005 & -7.900 \\
\hline 25-August & -15 & 0.689 & 1.160 & -7.210 \\
\hline 26- August & -14 & -0.125 & 0.210 & -7.335 \\
\hline 27-August & -13 & 0.927 & 1.560 & -6.408 \\
\hline 28-August & -12 & 1.083 & $1.822 *$ & -5.325 \\
\hline 31- August & -11 & 1.250 & $2.103 * *$ & -4.075 \\
\hline 01- September & -10 & 1.297 & $2.182 * *$ & -2.778 \\
\hline 02- September & -9 & 0.291 & 0.490 & -2.486 \\
\hline 03-September & -8 & 0.425 & 0.715 & -2.062 \\
\hline 04- September & -7 & 0.613 & 1.031 & -1.449 \\
\hline 07- September & -6 & 0.008 & 0.014 & -1.440 \\
\hline 08- September & -5 & 0.648 & 1.090 & -0.793 \\
\hline 09- September & -4 & -0.410 & 0.689 & -1.203 \\
\hline 10- September & -3 & -1.432 & $2.409 * *$ & -2.634 \\
\hline 11- September & -2 & -0.580 & 0.976 & -3.215 \\
\hline 14- September & -1 & 0.924 & 1.555 & -2.291 \\
\hline 15- September & 0 & -0.674 & 1.134 & -2.965 \\
\hline 16- September & 1 & -1.185 & $1.994 * *$ & -4.150 \\
\hline 17- September & 2 & 0.124 & 0.209 & -4.026 \\
\hline 18- September & 3 & -0.025 & 0.043 & -4.051 \\
\hline 21- September & 4 & -0.000 & 0.000 & -4.051 \\
\hline 22- September & 5 & 0.040 & 0.067 & -4.011 \\
\hline 23- September & 6 & 0.327 & 0.551 & -3.684 \\
\hline 24- September & 7 & 0.048 & 0.081 & -3.636 \\
\hline 25- September & 8 & 0.048 & 0.081 & -3.588 \\
\hline 28- September & 9 & 0.034 & 0.057 & -3.554 \\
\hline 29- September & 10 & 0.467 & 0.786 & -3.087 \\
\hline 30- September & 11 & -0.190 & 0.319 & -3.277 \\
\hline 01- October & 12 & 0.048 & 0.081 & -3.229 \\
\hline 02- October & 13 & 0.529 & 0.890 & -2.700 \\
\hline 05- October & 14 & -0.087 & 0.147 & -2.787 \\
\hline 06- October & 15 & 0.680 & 1.144 & -2.107 \\
\hline 07- October & 16 & 0.778 & 1.308 & -1.330 \\
\hline 08- October & 17 & -0.380 & 0.639 & -1.710 \\
\hline 09- October & 18 & 0.167 & 0.280 & -1.543 \\
\hline 12- October & 19 & 0.000 & 0.000 & -1.543 \\
\hline 13- October & 20 & -0.329 & 0.553 & -1.872 \\
\hline
\end{tabular}

Note: $n=15 ; * * *, * *$ and $*$ indicate significance at levels of $1 \%, 5 \%$ and $10 \%$ respectively. 
Table 2: Treasury Single Account Policy related Announcements and CAARs (Estimation window: -280, -31)

\begin{tabular}{lccc}
\multicolumn{1}{c}{ Date } & Event Period & CAAR $(\%)$ & t-test \\
\hline $4^{\text {th }}$ August- $14^{\text {th }}$ September, 2015 & $-30,-1$ & -2.291 & $6.343^{* * * *}$ \\
$4^{\text {th }}$ August- $13^{\text {th }}$ October, 2015 & $-30,20$ & -1.872 & $6.758^{* * *}$ \\
$10^{\text {th }}$ August- 20 ${ }^{\text {th }}$ August, 2015 & $-26,-18$ & -5.713 & $8.664^{* * *}$ \\
$10^{\text {th }}$ September- $18^{\text {th }}$ September, 2015 & $-3,3$ & -2.849 & $3.810^{* * *}$ \\
$16^{\text {th }}$ September- 29 ${ }^{\text {th }}$ September, 2015 & 1,10 & -0.122 & 0.195 \\
$21^{\text {st }}$ September- 30 & \\
$1^{\text {th }}$ September, 2015 & 4,11 & 0.415 & 0.593 \\
\hline
\end{tabular}

CAAR represent significant announcements within the event period. Statistical significance levels are represented by $* * *, * *, *$ at $1 \%, 5 \%$ and $10 \%$ respectively.
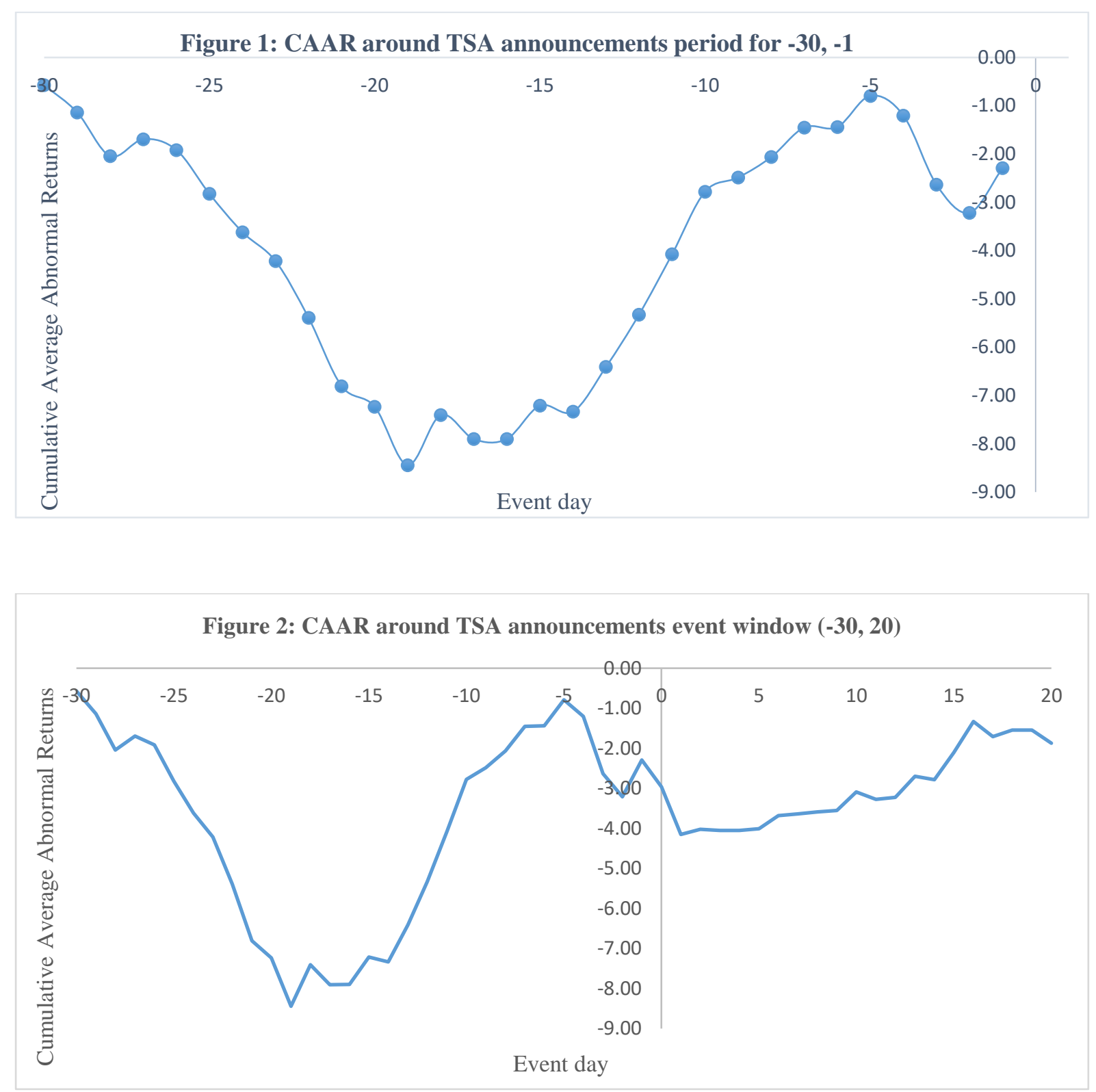
Figure S1: CAAR around TSA announcements event period $(-3,3)$

\begin{tabular}{llllll}
\hline & -2 & -1 & & 0.00 \\
\hline
\end{tabular}


Table S1: Average Abnormal Returns (AARs) during the Event Window (Estimation window: -180, -31)

\begin{tabular}{|c|c|c|c|c|}
\hline Date & Event Window & $\operatorname{AARs}(\%)$ & t-value & CAARs (\%) \\
\hline 04- August & -30 & -0.413 & 0.68 & -0.413 \\
\hline 05-August & -29 & -0.573 & 0.95 & -0.986 \\
\hline 06- August & -28 & -1.028 & $1.70 *$ & -2.014 \\
\hline 07- August & -27 & 0.289 & 0.48 & -1.725 \\
\hline 10-August & -26 & -0.299 & 0.49 & -2.024 \\
\hline 11- August & -25 & -0.827 & 1.37 & -2.850 \\
\hline 12- August & -24 & -0.858 & 1.42 & -3.708 \\
\hline 13- August & -23 & -0.718 & 1.19 & -4.426 \\
\hline 14- August & -22 & -1.155 & $1.91 * *$ & -5.582 \\
\hline 17- August & -21 & -1.313 & $2.17 * *$ & -6.895 \\
\hline 18- August & -20 & -0.542 & 0.90 & -7.436 \\
\hline 19- August & -19 & -1.292 & $2.14 * *$ & -8.728 \\
\hline 20- August & -18 & 1.101 & $1.82 *$ & -7.627 \\
\hline 21- August & -17 & -0.546 & 0.90 & -8.173 \\
\hline 24- August & -16 & -0.059 & 0.10 & -8.232 \\
\hline 25- August & -15 & 0.638 & 1.05 & -7.594 \\
\hline 26- August & -14 & -0.106 & 0.18 & -7.700 \\
\hline 27- August & -13 & 0.970 & 1.60 & -6.730 \\
\hline 28- August & -12 & 1.225 & $2.03 * *$ & -5.505 \\
\hline 31- August & -11 & 1.376 & $2.28 * *$ & -4.129 \\
\hline 01- September & -10 & 1.371 & $2.27 * *$ & -2.758 \\
\hline 02- September & -9 & 0.266 & 0.44 & -2.492 \\
\hline 03-September & -8 & 0.558 & 0.92 & -1.934 \\
\hline 04- September & -7 & 0.739 & 1.22 & -1.195 \\
\hline 07- September & -6 & 0.110 & 0.18 & -1.085 \\
\hline 08-September & -5 & 0.760 & 1.26 & -0.325 \\
\hline 09- September & -4 & -0.473 & 0.78 & -0.797 \\
\hline 10- September & -3 & -1.585 & $2.62 * * *$ & -2.382 \\
\hline 11- September & -2 & -0.531 & 0.88 & -2.913 \\
\hline 14- September & -1 & 0.979 & 1.62 & -1.934 \\
\hline 15- September & 0 & -0.711 & 1.18 & -2.645 \\
\hline 16- September & 1 & -1.080 & $1.79 *$ & -3.724 \\
\hline 17- September & 2 & 0.164 & 0.27 & -3.560 \\
\hline 18- September & 3 & 0.056 & 0.09 & -3.504 \\
\hline 21- September & 4 & 0.023 & 0.04 & -3.481 \\
\hline 22- September & 5 & -0.012 & 0.02 & -3.493 \\
\hline 23- September & 6 & 0.337 & 0.56 & -3.156 \\
\hline 24- September & 7 & 0.058 & 0.10 & -3.098 \\
\hline 25- September & 8 & 0.058 & 0.10 & -3.040 \\
\hline 28- September & 9 & -0.065 & 0.11 & -3.105 \\
\hline 29- September & 10 & 0.379 & 0.63 & -2.726 \\
\hline 30- September & 11 & -0.307 & 0.51 & -3.033 \\
\hline 01- October & 12 & 0.058 & 0.10 & -2.976 \\
\hline 02- October & 13 & 0.689 & 1.14 & -2.286 \\
\hline 05- October & 14 & -0.043 & 0.07 & -2.330 \\
\hline 06- October & 15 & 0.716 & 1.18 & -1.613 \\
\hline 07- October & 16 & 0.675 & 1.12 & -0.938 \\
\hline 08- October & 17 & -0.411 & 0.68 & -1.349 \\
\hline 09- October & 18 & 0.228 & 0.38 & -1.121 \\
\hline 12- October & 19 & 0.056 & 0.09 & -1.064 \\
\hline 13- October & 20 & -0.235 & 0.39 & -1.299 \\
\hline
\end{tabular}

This table contains robustness results for the test sample using estimation window of 150-days (-180, -31). Note $n=15 ; * * *, * *$ and ${ }^{*}$ indicate significance at levels of $1 \%, 5 \%$ and $10 \%$ respectively 
Table S2: Treasury Single Account Policy related Announcements and CAARs (Estimation window: -180, -31)

\begin{tabular}{|c|c|c|c|}
\hline Date & Event Period & CAAR (\%) & t-test \\
\hline $4^{\text {th }}$ August- $14^{\text {th }}$ September, 2015 & $-30,-1$ & -1.934 & $4.013 * * *$ \\
\hline $4^{\text {th }}$ August- $13^{\text {th }}$ October, 2015 & $-30,20$ & -1.299 & $3.515 * * *$ \\
\hline $10^{\text {th }}$ August- $20^{\text {th }}$ August, 2015 & $-26,-18$ & -5.902 & $6.709 * * *$ \\
\hline $10^{\text {th }}$ September- $18^{\text {th }}$ September, 2015 & $-3,3$ & -2.707 & $2.713 * * *$ \\
\hline $16^{\text {th }}$ September- $29^{\text {th }}$ September, 2015 & 1,10 & -0.081 & 0.097 \\
\hline $21^{\text {st }}$ September- $30^{\text {th }}$ September, 2015 & 4,11 & 0.471 & 0.505 \\
\hline $1^{\text {st }}$ October- $13^{\text {th }}$ October, 2015 & 12,20 & 1.734 & $1.971 * *$ \\
\hline
\end{tabular}

CAAR represent significant announcements within the event period. Statistical significance levels are represented by $* * *, * *, *$ at $1 \%, 5 \%$ and $10 \%$ respectively. 
Table S3a: Average Abnormal Returns during the Announcement period using 250-day Estimation window

\begin{tabular}{ccccc}
\hline Date & Event Period (-3,3) & AARs (\%) & t-value & CAARs (\%) \\
\hline 4-August & -3 & -0.570 & 0.959 & -0.570 \\
5- August & -2 & -0.568 & 0.956 & -1.138 \\
6- August & -1 & -0.905 & 1.522 & -2.042 \\
7- August & 0 & 0.350 & 0.589 & -1.692 \\
10- August & 1 & -0.223 & 0.375 & -1.915 \\
11- August & 2 & -0.908 & 1.528 & -2.823 \\
12- August & 3 & -0.794 & 1.336 & -3.617 \\
\hline
\end{tabular}

Table S3b: Treasury Single Account Policy Announcement period and CAARs using 250-day Estimation window Date

$4^{\text {th }}$ August $-12^{\text {th }}$ August, 2015 Event Period CAARs (\%) $-3.617$ T-test

CAAR represent significant announcements within the event period. Statistical significance levels are represented by $* * *$, $* *, *$ at $1 \%, 5 \%$ and $10 \%$ respectively.

Table S4a: Average Abnormal Returns during the Announcement period using 150-day Estimation window

\begin{tabular}{lcccc}
\hline Date & Event Period (-3,3) & AARs $(\%)$ & t-value & CAARs $(\%)$ \\
\hline 4-August & -3 & -0.413 & 0.68 & -0.413 \\
5- August & -2 & -0.573 & 0.95 & -0.986 \\
6- August & -1 & -1.028 & $1.70 *$ & -2.014 \\
7- August & 0 & 0.289 & 0.48 & -1.725 \\
10- August & 1 & -0.299 & 0.49 & -2.024 \\
11- August & 2 & -0.827 & 1.37 & -2.85 \\
12- August & 3 & -0.858 & 1.42 & -3.708 \\
\hline
\end{tabular}

Table S4b: Treasury Single Account Policy Announcement period and CAARs using 150-day Estimation window

\begin{tabular}{lccc}
\hline Date & Event Period & CAARs (\%) & T-test \\
\hline $4^{\text {th }}$ August $-12^{\text {th }}$ August, 2015 & $-3,3$ & -3.708 & $3.717 * * *$ \\
\hline CAAR represent significant announcements within the event period. Statistical significance levels are represented by \\
$* * *, * * *$ at $1 \%, 5 \%$ and $10 \%$ respectively.
\end{tabular}


Appendix S1: Final sample of listed commercial Banks in Nigeria

\begin{tabular}{ccl}
\hline UNIQUE & TICKER & \\
IDENTIFIER & SYMBOL & COMMERCIAL BANK \\
\hline 100 & ACC & Access Bank Plc \\
200 & GTB & Guaranty Trust Bank \\
300 & UBN & Union Bank of Nigeria \\
400 & UBA & United Bank for Africa \\
500 & WEM & Wema Bank \\
600 & ZIB & Zenith International Bank \\
700 & FCM & First City Monument Bank \\
800 & STN & StanbicIBTC Holding \\
900 & FDB & Fidelity Bank \\
1000 & DBN & Diamond Bank Nigeria \\
1100 & UBK & Unity Bank \\
1200 & SBK & Skye Bank \\
1300 & FBN & First Bank of Nigeria Holdings \\
1400 & ETI & Ecobank Transnational \\
1500 & SLB & Sterling Bank \\
\hline
\end{tabular}

Note: The Unique Identifier was developed by authors for STATA computational purposes only. 
Consequences of the Treasury Single Account Policy on the Wealth of Nigerian Commercial Banks' Shareholders

Moses, $\mathrm{O}$

2018

22/04/2023 - Downloaded from MASSEY RESEARCH ONLINE 